\title{
Trends in Pharmacognosy: 35 Years of Research on Therapeutical Natural Resources
}

\author{
Rogelio Pereda-Miranda ${ }^{1}\left[\right.$ [ $\cdot$ Cid Aimbiré de Moraes Santos ${ }^{2}(\mathbb{C}$
}

Published online: 12 November 2021

(C) The Author(s) under exclusive licence to Sociedade Brasileira de Farmacognosia 2021

Natural medicines have been used since time immemorial to improve human and veterinary health. This human need for medicines is so extensive as to be thought a deep evolutionary behavior (Hardy 2021). The success of modern medical science has largely depended on drugs originally obtained from natural resources, which is the focus of pharmacognosy, a profile discipline of the pharmaceutical sciences dedicated to study the physical, chemical, biochemical, and biological properties of drugs, drug substances, or potential drugs of natural origin. The goal of our discipline is to discover sources of natural drugs and products of their metabolism from plants, microorganisms, fungi, algae, and animals for the treatment of diseases.

In the twenty-first century, pharmacognosy has become a multidisciplinary, high-tech science of natural medicines in terms of assaying their purity, potency, and consistency, especially in its methodology of using faster and more effective analytical methods, high-throughput screening, target-based drug discovery, and in silico methods for virtual ligand screening. Molecular pharmacognosy (Alamgir 2018), genomic pharmacognosy (Yang et al. 2019), and metabolomic pharmacognosy (Allard et al. 2018) have been contemplated as the most promising approaches of pharmacognosy research to meet emergent trends in molecular biology, biotechnology, and analytical chemistry of natural medicines. For example, nowadays DNA barcoding represents an essential addition to the wide range of robust methodologies

This article is part of a Special Issue to celebrate the 35 th anniversary of the Brazilian Journal of Pharmacognosy.

Rogelio Pereda-Miranda

bjp@sbfgnosia.org.br

$\triangle$ Cid Aimbiré de Moraes Santos

revista@sbfgnosia.org.br

1 Universidad Nacional Autónoma de México, Mexico City, Mexico

2 Universidade Federal do Paraná, Curitiba, Brazil used to identify and authenticate natural drugs and their pharmaceutical products (Gesto-Borroto et al. 2021).

In 1984, Revista Brasileira de Farmacognosia (RBF), Brazilian Journal of Pharmacognosy, was a dream of pharmacist Fernando de Oliveira, an esteemed professor of pharmacognosy at the University of São Paulo. As Professor de Oliveira became president of the Brazilian Society of Pharmacognosy, Sociedade Brasileira de Farmacognosia (SBFgnosia), he set as a "main goal" of his term to establish a journal as an official organ of the society that would stimulate and disseminate the study and knowledge of pharmacognosy in Brazil and abroad, emphasizing the analysis of plant drugs from megadiverse Brazil.

Volume 1, Issue 1, of RBF was published in July 1986. SBFgnosia's treasurer reported at the time that this edition cost almost three times the society's financial reserve. That dearth of resources did not deter the Editorial Board led by Professor de Oliveira to complete the publication of the first volume. That dream remains a reality in the light of day as the RBF has now accomplished the publication of 31 volumes.

The Board of SBFgnosia, to honor its former editors, invited Prof. Cláudia Maria Oliveira Simões (1999-2004), Prof. João Carlos Palazzo de Mello (1999-2004), and Prof. Maique Weber Biavatti (2017-2019) to act as Guest Editors of this commemorative special issue to celebrate the 35 th anniversary of our journal.

Trends in Pharmacognosy assembles reviews, original articles, and short communications that highlight some of the major challenges that might drive research in this discipline remarkably forward. These pieces consider the evaluation of ethnopharmacological plant sources, the application of high-resolution analytical methods for structural elucidation, purification of biodynamic metabolites and metabolomics, and the pharmacognosy of organisms from the Poles of the Earth and of microorganisms from various other biomes in the discovery of new pharmacological therapies. 
The significance of all these contributions demonstrates the importance of natural product research to promote rational use of bioprospecting studies in developing countries. The impact will be strong on diversity conservation, sustainable management of natural sources, and economic development that combats wealth inequity in these regions.

Over the years, RBF's credibility has grown, as it has continued contributing to researchers from Brazil and abroad with exciting new developments in all areas of interest of pharmacognosy in its pages. This year, RBF has achieved an Impact Factor of 2.01. We hope and trust that over the next 35 years and beyond, Revista Brasileira de Farmacognosia will remain committed to being an authoritative source of natural drug information for therapeutical purposes.

\section{Declarations}

The authors bear sole responsibility for the views presented in this editorial.

\section{References}

Alamgir ANM (2018) Molecular pharmacognosy. A new borderline discipline between molecular biology and pharmacognosy. In: Rainsford KD (ed) Therapeutic use of medicinal plants and their extracts: Volume 2. Phytochemistry and bioactive compounds. Progress in Drug Research, vol 74. Springer, Cham, pp. 665-720. https://doi.org/10.1007/978-3-319-92387-1_8

Allard PM, Bisson J, Azzollini A, Pauli GF, Cordell GA, Wolfender JL (2018) Pharmacognosy in the digital era: shifting to contextualized metabolomics. Curr Opin Biotechnol 54:57-64. https://doi. org/10.1016/j.copbio.2018.02.010

Gesto-Borroto R, Medina-Jiménez K, Lorence A, Villarreal ML (2021) Application of DNA barcoding for quality control of herbal drugs and their phytopharmaceuticals. Rev Bras Farmacogn 31:127141. https://doi.org/10.1007/s43450-021-00128-7

Hardy K (2021) Paleomedicine and the evolutionary context of medicinal plant use. Rev Bras Farmacogn 31:1-15. https://doi.org/10. 1007/s43450-020-00107-4

Yang J, Jia M, Guo J (2019) Functional genome of medicinal plants. In: Huang L-Q (ed) Molecular pharmacognosy. Springer, Singapore, pp 191-234. https://doi.org/10.1007/978-981-32-9034-1_7 